\title{
Proteomics of Host-Helminth Interactions
}

\author{
Mark W. Robinson ${ }^{1, *(D)}$ and Krystyna Cwiklinski ${ }^{2, *}$ \\ 1 School of Biological Sciences, Queen's University Belfast, 19 Chlorine Gardens, Belfast BT9 5DL, \\ Northern Ireland, UK \\ 2 Center of One Health $(\mathrm{COH})$ and Ryan Institute, School of Natural Science, National University of Ireland \\ Galway, H91 DK59 Galway, Ireland \\ * Correspondence: mark.robinson@qub.ac.uk (M.W.R.); krystyna.cwiklinski@nuigalway.ie (K.C.)
}

check for updates

Citation: Robinson, M.W.; Cwiklinski, K. Proteomics of Host-Helminth Interactions. Pathogens 2021, 10, 1317. https://doi.org/10.3390/ pathogens 10101317

Received: 8 October 2021 Accepted: 11 October 2021 Published: 13 October 2021

Publisher's Note: MDPI stays neutral with regard to jurisdictional claims in published maps and institutional affiliations.

Copyright: (c) 2021 by the authors. Licensee MDPI, Basel, Switzerland. This article is an open access article distributed under the terms and conditions of the Creative Commons Attribution (CC BY) license (https:/ / creativecommons.org/licenses/by/ $4.0 /)$.
Helminth infections in people contribute to the 1.31 billion cases of neglected tropical diseases and malaria worldwide, representing a loss of 10.6 million disability adjusted life years each year [1]. The diseases caused by these parasites are endemic in over 100 countries where they typically affect people living in poverty and, accordingly, the World Health Organisation recognises them as some of the world's most neglected tropical diseases [2,3]. Helminth parasites also have a major negative impact on animal production and welfare, accounting for $>55 \%$ of all farm animal disease and approximately $17 \%$ of animal production losses [4,5].

With their complex life cycles and varied developmental stages, each with distinct biology and host interactions, effective treatment of helminth infection can be challenging. For most species, we are reliant on only a few drugs (e.g., praziquantel and ivermectin), but these do not prevent reinfection and require repeated usage. Indeed, this is not sustainable in the long term, due to the threat of drug resistance, and has led to considerable research effort toward the development of first-generation helminth vaccines (reviewed by Claerebout and Geldhof, 2020 [6] and Perera and Ndao, 2021 [7]). This has not been straightforward and has indeed been hampered by the striking ability of helminths to modulate host immune responses [8-10]. It has become evident that new strategies to prevent and treat helminth infections are dependent on a deeper understanding of helminth-host interactions. A major task is to identify virulence factors/immunomodulatory molecules that are essential for parasite survival which may serve as novel vaccine candidates or as targets for anthelmintic drugs. Accordingly, mass spectrometry-based proteomics techniques, which have revolutionised our ability to identify helminth proteins over the past 20 years, will continue to have a key role in this process.

In this Special Issue, which focuses on the proteomics of host-helminth interactions, there are nine timely contributions which highlight recent advances in this field but also bring into focus some research priorities moving forward. The collection includes four research papers. The first of these, by Długosz et al., focuses on the zoonotic nematode Toxocara canis [11]. In this study the authors used a yeast two-hybrid assay to identify human proteins that may directly interact with $T$. canis antigens. As such, the study provides an initial basis for understanding the immunological and pathological effects of this infection in humans. Next, Wititkornkul et al. examine the immunomodulatory potential of extracellular vesicles (EVs) released by the equine tapeworm Anoplocephala perfoliata [12]. EVs have emerged as novel vehicles for transfer of helminth-derived molecules to host cells, and, by describing the cargo of $A$. perfoliata EVs, this paper uncovers potential mechanisms of parasite-to-host communication during infection. The next research paper by Lan et al., together with that of Becerro-Recio et al., focuses on the identification of antigens secreted by the liver fluke, Fasciola hepatica, that are recognised by the host immune response [13,14]. Here, readers will be able to compare and contrast the different experimental approaches taken by these authors (co-immunoprecipitation vs. two-dimensional Western blot, both coupled with mass spectrometry) to profile antigenic molecules shed by the liver fluke during infection of sheep. 
The next five articles are reviews covering the interactions of nematode and trematode parasites with their mammalian hosts. Thiangtrongjit et al. discuss how profiling the secretome of Gnathostoma spinigerum, a zoonotic nematode infection, coupled with immunoproteomics approaches, is driving the development of novel diagnostic tools for human gnathostomiasis [15]. The next review article by Carson and Gobert highlights how recent comparative proteomics analysis has advanced our understanding of the antigens released by schistosome eggs and how these drive immunological and pathological responses in host tissue [16]. The next two review articles by Wang and Gasser and Bennett and Robinson summarise progress in the use of mass spectrometry-based proteomics techniques to study nematode and trematode parasites, respectively. With an emphasis on emerging technologies, both reviews pin-point key research areas that will enhance our understanding of host-helminth interactions with a view toward new methods of treatment and diagnosis $[17,18]$. Finally, Porras-Silesky et al. review the current understanding of how the nematode parasite, Spirocerca lupi, induces cancer in dogs [19]. By discussing the role of specific secreted antigens from other carcinogenic helminths (such as Clonorchis sinensis, Opisthorchis viverrini and Schistosoma haematobium, and other lesser studied species) they propose a mechanism for S. lupi-induced cancer in dogs which is underpinned by sustained inflammatory responses to parasite antigens.

In summary, by inviting articles from leading helminth researchers, the aim of this Special Issue was to highlight how mass spectrometry-based proteomics has advanced our understanding of the host-parasite interaction. We hope that the articles compiled will stimulate discussion and further research in this area and contribute to the development of new strategies for helminth diagnosis and control.

Conflicts of Interest: The authors declare no conflict of interest.

\section{References}

1. GBD 2019 Diseases and Injuries Collaborators. Global burden of 369 diseases and injuries in 204 countries and territories, 1990-2019: A systematic analysis for the Global Burden of Disease Study 2019. Lancet 2020, 396, 204-1222.

2. WHO. World Health Organization. Available online: http://www.who.int/neglected_diseases/diseases/en/ (accessed on 11 January 2021).

3. Hotez, P.J.; Brindley, P.J.; Bethony, J.M.; King, C.H.; Pearce, E.J.; Jacobson, J. Helminth infections: The great neglected tropical diseases. J. Clin. Investig. 2008, 118, 1311-1321. [CrossRef] [PubMed]

4. Charlier, J.; Thamsborg, S.M.; Bartley, D.J.; Skuce, P.J.; Kenyon, F.; Geurden, T.; Hoste, H.; Williams, A.R.; Sotiraki, S.; Höglund, J.; et al. Mind the gaps in research on the control of gastrointestinal nematodes of farmed ruminants and pigs. Transbound Emerg Dis. 2018, 65 (Suppl. S1), 217-234. [CrossRef] [PubMed]

5. Charlier, J.; Rinaldi, L.; Musella, V.; Ploeger, H.W.; Chartier, C.; Vineer, H.R.; Hinney, B.; von Samson-Himmelstjerna, G.; Băcescu, B.; Mickiewicz, M.; et al. Initial assessment of the economic burden of major parasitic helminth infections to the ruminant livestock industry in Europe. Prev. Vet. Med. 2020, 182, 105103. [CrossRef]

6. Claerebout, E.; Geldhof, P. Helminth Vaccines in Ruminants: From Development to Application. Vet. Clin. N.Am. Food Anim Pract. 2020, 36, 159-171. [CrossRef]

7. Perera, D.J.; Ndao, M. Promising Technologies in the Field of Helminth Vaccines. Front. Immunol. 2021, 12, 711650. [CrossRef]

8. Maizels, R.M.; Smits, H.H.; McSorley, H.J. Modulation of Host Immunity by Helminths: The Expanding Repertoire of Parasite Effector Molecules. Immunity 2018, 49, 801-818. [CrossRef] [PubMed]

9. Wiedemann, M.; Voehringer, D. Immunomodulation and Immune Escape Strategies of Gastrointestinal Helminths and Schistosomes. Front. Immunol. 2020, 11, 572865. [CrossRef] [PubMed]

10. Ryan, S.; Shiels, J.; Taggart, C.C.; Dalton, J.P.; Weldon, S. Fasciola hepatica-Derived Molecules as Regulators of the Host Immune Response. Front. Immunol. 2020, 11, 2182. [CrossRef] [PubMed]

11. Długosz, E.; Milewska, M.; Baska, P. Identification of Toxocara canis Antigen-Interacting Partners by Yeast Two-Hybrid Assay and a Putative Mechanism of These Host-Parasite Interactions. Pathogens 2021, 10, 949. [CrossRef] [PubMed]

12. Wititkornkul, B.; Hulme, B.J.; Tomes, J.J.; Allen, N.R.; Davis, C.N.; Davey, S.D.; Cookson, A.R.; Phillips, H.C.; Hegarty, M.J.; Swain, M.T.; et al. Evidence of Immune Modulators in the Secretome of the Equine Tapeworm Anoplocephala perfoliata. Pathogens 2021, 10, 912. [CrossRef] [PubMed]

13. Lan, Z.; Liu, X.L.; Lv, Q.B.; Zeng, M.H.; Gao, J.F.; Chang, Q.C.; Chen, Y.Y.; Wang, C.R. Proteomic Analysis of Fasciola hepatica Excretory and Secretory Products Co-Immunoprecipitated Using Time Course Infection Sera. Pathogens 2021, 10, 749. [CrossRef] 
14. Becerro-Recio, D.; González-Miguel, J.; Ucero, A.; Sotillo, J.; Martínez-Moreno, Á.; Pérez-Arévalo, J.; Cwiklinski, K.; Dalton, J.P.; Siles-Lucas, M. Recognition Pattern of the Fasciola hepatica Excretome/Secretome during the Course of an Experimental Infection in Sheep by 2D Immunoproteomics. Pathogens 2021, 10, 725. [CrossRef]

15. Thiangtrongjit, T.; Nogrado, K.; Ketboonlue, T.; Malaitong, P.; Adisakwattana, P.; Reamtong, O. Proteomics of Gnathostomiasis: A Way Forward for Diagnosis and Treatment Development. Pathogens 2021, 10, 1080. [CrossRef]

16. Carson, J.P.; Gobert, G.N. Modulation of the Host Immune Response by Schistosome Egg-Secreted Proteins Is a Critical Avenue of Host-Parasite Communication. Pathogens 2021, 10, 863. [CrossRef] [PubMed]

17. Wang, T.; Gasser, R.B. Prospects of Using High-Throughput Proteomics to Underpin the Discovery of Animal Host-Nematode Interactions. Pathogens 2021, 10, 825. [CrossRef] [PubMed]

18. Bennett, A.P.S.; Robinson, M.W. Trematode Proteomics: Recent Advances and Future Directions. Pathogens $2021,10,348$. [CrossRef] [PubMed]

19. Porras-Silesky, C.; Mejías-Alpízar, M.J.; Mora, J.; Baneth, G.; Rojas, A. Spirocerca lupi Proteomics and Its Role in Cancer Development: An Overview of Spirocercosis-Induced Sarcomas and Revision of Helminth-Induced Carcinomas. Pathogens 2021, 10, 124. [CrossRef] [PubMed] 